\title{
A DEADBEAT CONTROLLER FOR DOUBLY-FED INDUCTION GENERATOR POWER CONTROL
}

\author{
Alfeu J. Sguarezi Filho, J. L. Azcue P., T. A. S. Barros, M. E. Oliveira Filho and E. Ruppert \\ University of Campinas \\ FEEC-DSCE-UNICAMP CEP 13083 - 852, Caixa Postal 6101, Campinas - SP, Brasil
}

(sguarezi, azcue, mfilho)@dsce.fee.unicamp.br, tarcioandre@hotmail.com and ruppert@fee.unicamp.br

\begin{abstract}
A deadbeat power control scheme for doubly-fed induction generator for variable speed was proposed. The deadbeat controller algorithm calculates the voltage vector to be supplied to the rotor in order to eliminate the active and reactive power errors in each period using and stator field orientation and the doublyfed induction generator dynamic model. The deadbeat controller uses the rotor current control to the power control of the machine. This control technique can be applied to the wind energy systems. Experimental results are carried out to validate of the deadbeat controller operation.
\end{abstract}

Keywords - Doubly-fed Induction Generator, Deadbeat Control, Power Control, Variable Speed Constant Frequency Applications.

\section{INTRODUCTION}

The renewable energy systems and specially wind energy have attracted interest due to the increasing concern about $\mathrm{CO}_{2}$ emissions. The wind energy systems using a doublyfed induction generator (DFIG) have some advantages due to variable speed operation and four quadrant active and reactive power capabilities compared with fixed speed induction generators and lower cost when compared with solar energy $[1,2]$.

In wind energy systems the stator of DFIG is direct connected to the grid and the rotor links the grid by a bidirectional converter as shown in Figure 1. The rotor converter objective aims to the DFIG active and reactive power control between the stator and ac supply.

The power control of DFIG is traditionally based on either stator-flux-oriented [3] or stator-voltage-oriented [4] vector control. Some investigations using PI controllers that generates reference currents from active and reactive power errors to the inverter or a cascade PI controllers that generate a rotor voltage which have been presented by [3,5-7]. The problem in the use of PI controller is the tuning of the gains and the cross-coupling on DFIG terms. An interesting method to solve these problems have been presented by [8-10].

Some investigations for DFIG power control by using predictive functional controller [11], internal mode controller $[12,13]$ and predictive control $[14,15]$ have satisfactory power response when compared with the power response of PI but it is hardly to implement one due to the formulation of the controllers.

Manuscript received 06/07/2011; revised 09/11/2011. Accepted for publication 23/11/2011 by recommendation of the Editor Prof. João Onofre Pereira Pinto.
To improve the power response and to protection of rotorside converter under grid voltage sags with stator voltage orientation a proportional control with anti-jamming control which has been proposed by [16]. This control has satisfactory power response and eliminate the rotor current overshoot in voltage sags although power and rotor currents results was shown only in super-synchronous DFIG operation and the proportional controller needs to be carefully tuned to ensure system stability and adequate response within the whole operating range.

This paper proposes an alternative solution to power control presented in [17] by using the doubly-fed induction generator dynamic discrete equations when DFIG operates with variable speed. The deadbeat control for DFIG power control aims the active and reactive power control using the DFIG dynamic equations in synchronous coordinate system using the stator flux position. The controller calculates the rotor voltages required to guarantee active and reactive power reach their desired reference values in a few sampling intervals in which simulations results were presented in [18]. The deadbeat controller uses the rotor current control to the power control of the machine. This power control technique can be applied to the DIFG for wind energy systems due to the fact the wind speed is uncertain and the controller also operates with variable speed. Experimental results are presented to validate of the proposed controller.

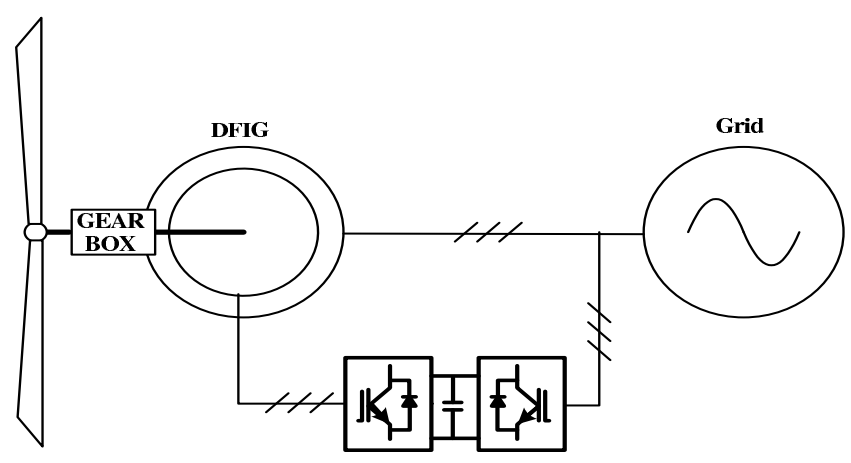

Fig. 1. Configuration of DFIG connected direct on grid.

\section{MACHINE MODEL AND VECTOR CONTROL}

Doubly-fed induction machine model in synchronous reference frame is given by

$$
\vec{v}_{1 d q}=R_{1} \vec{i}_{1 d q}+\frac{d \vec{\lambda}_{1 d q}}{d t}+j \omega_{1} \vec{\lambda}_{1 d q}
$$

$$
\vec{v}_{2 d q}=R_{2} \vec{i}_{2 d q}+\frac{d \vec{\lambda}_{2 d q}}{d t}+j\left(\omega_{1}-N P \omega_{m e c}\right) \vec{\lambda}_{2 d q}
$$


the relationship between fluxes and currents

$$
\begin{aligned}
& \vec{\lambda}_{1 d q}=L_{1} \vec{i}_{1 d q}+L_{M} \vec{i}_{2 d q} \\
& \vec{\lambda}_{2 d q}=L_{M} \vec{i}_{1 d q}+L_{2} \vec{i}_{2 d q}
\end{aligned}
$$

and generator active and reactive power are

$$
\begin{aligned}
& P=\frac{3}{2}\left(v_{1 d} i_{1 d}+v_{1 q} i_{1 q}\right) \\
& Q=\frac{3}{2}\left(v_{1 q} i_{1 d}-v_{1 d} i_{1 q}\right)
\end{aligned}
$$

where $\vec{v}, \vec{i}, \vec{\lambda}$ are voltage, currents and flux space vectors, respectively, $R$ is resistance of the winding, $L$ is inductance of the winding, the subscripts $1,2, M$ denotes stator, rotor and mutual, $N P$ is the pole pairs and $\omega_{m e c}$ is the rotor speed. The parameters estimation of the induction machine were made using the method presented in [19].

The DFIG power control aims independent stator active $P$ and reactive $Q$ power control by means a rotor current regulation. For this purpose, $P$ and $Q$ are represented as functions of each individual rotor current space vector components. Using stator flux oriented control, that decouples $d q$ axis (3) becomes

$$
\begin{gathered}
i_{1 d}=\frac{\lambda_{1}}{L_{1}}-\frac{L_{M}}{L_{1}} i_{2 d} \\
i_{1 q}=-\frac{L_{M}}{L_{1}} i_{2 q}
\end{gathered}
$$

and the active (5) and reactive (6) power can be calculated by using Equations (7) and (8) and it is given by

$$
\begin{gathered}
P=-\frac{3}{2} v_{1} \frac{L_{M}}{L_{1}} i_{2 q} \\
Q=\frac{3}{2} v_{1}\left(\frac{\lambda_{1}}{L_{1}}-\frac{L_{M}}{L_{1}} i_{2 d}\right)
\end{gathered}
$$

Thus, rotor currents will reflect in stator currents and on stator active and reactive power. Consequently, this principle can be used on stator active and reactive power control by using current control on rotor side of the DFIG with stator direct connected to the grid.

\section{A. Rotor Side Equations}

The control of rotor currents allows the DFIG power control as can be seen in (9) and (10). The rotor voltage (2), in the synchronous referential frame using the stator flux position, Equations (7) and (8) becomes

$\vec{v}_{2 d q}=\left(R_{2}+j L_{2} \omega_{s l}\right) \vec{i}_{2 d q}+j L_{m} \omega_{s l} \vec{i}_{1 d q}+\left(L_{2}-\frac{L_{M}^{2}}{L_{1}}\right) \frac{d \vec{i}_{2 d q}}{d t}$

where $\omega_{s l}=\omega_{1}-P \omega_{m e c}$.

In space state form (11) becomes

$$
\frac{d \bar{i}_{2}}{d t}=H \bar{i}_{2}+K \bar{v}_{2}+L \bar{i}_{1}
$$

$$
\begin{array}{r}
{\left[\begin{array}{l}
\frac{d i_{2 d}}{d t} \\
\frac{d t 2 q}{d t}
\end{array}\right]=\left[\begin{array}{cc}
\frac{-R_{2}}{\sigma L_{2}} & \frac{\omega_{s l}}{\sigma} \\
\frac{\omega_{s l}}{\sigma} & \frac{-R_{2}}{\sigma L_{2}}
\end{array}\right]\left[\begin{array}{c}
i_{2 d} \\
i_{2 q}
\end{array}\right]+\left[\begin{array}{cc}
\frac{1}{\sigma L_{2}} & 0 \\
0 & \frac{1}{\sigma L_{2}}
\end{array}\right]\left[\begin{array}{l}
v_{2 d} \\
v_{2 q}
\end{array}\right]+} \\
{\left[\begin{array}{cc}
0 & \frac{\omega_{s l} L_{M}}{\sigma L_{2}} \\
\frac{-\omega_{s l} L_{M}}{\sigma L_{2}} & 0
\end{array}\right]\left[\begin{array}{l}
i_{1 d} \\
i_{1 q}
\end{array}\right]}
\end{array}
$$

where $\sigma=1-\frac{L_{M}^{2}}{L_{1} L_{2}}$.

From now it will be assumed that the mechanical time constant is much greater then the electrical time constants. Thus $\omega_{m e c}=$ constant is a valid approximation for each sampling time. As synchronous frequency is fixed by the grid, slip speed $\omega_{s l}=$ constant for each sampling time is also a valid approximation.

\section{THE DEADBEAT CONTROL}

The deadbeat control is a digital control technique that allows to calculate required input $\bar{u}(k)$ to guarantee that the output $\bar{x}(k)$ to will reach their desired reference values in in the smallest number of sampling intervals using a discrete equation of the continuous linear system which have been presented in [20]. For an Nth-order linear system, the minimum number of steps (sampling intervals) will be at most $N$ to the output reaches their desired reference values [20].

A linear continuous system is represented by

$$
\begin{array}{r}
\dot{\bar{x}}=A \bar{x}+B \bar{u}+G \bar{w} \\
\bar{y}=C \bar{x}
\end{array}
$$

where $\bar{w}$ denotes the pertubation vector and $A, C, B$ and $G$ $n \times n$ matrices. In this paper $C=I$, where $I$ is the identity matrix.

The Equation (14) can be discretized considering $T$ as the sampling period and $k$ as the sampling time by using zeroorder-hold ( $\mathrm{ZOH})$ with no delay as

$$
\bar{x}(k+1)=A_{d} \bar{x}(k)+B_{d} \bar{u}(k)+G_{d} \bar{w}(k)
$$

where

$$
\begin{array}{r}
A_{d}=e^{A T} \cong I+A T \\
B_{d}=\int_{0}^{\tau} e^{A T} B d \tau \cong B T \\
G_{d}=\int_{0}^{\tau} e^{A T} G d \tau \cong G T
\end{array}
$$

The input calculation to guarantee a null steady state error is given by

$$
\bar{u}(k)=F\left(\bar{x}_{r e f}-\bar{x}\right)
$$

where $\bar{x}_{r e f}$ is the reference vector and $F$ is the matrix gain.

Substituting (17) in (15) and making $\bar{x}_{\text {ref }}=\bar{x}(k+1)$ the input that guarantees a null steady state error is given by

$\bar{u}(k)=\underbrace{B_{d}^{-1} A_{d}}_{F}\left[A_{d}^{-1} \bar{x}(k+1)-\bar{x}(k)-A_{d}^{-1} G_{d} \bar{w}(k)\right]$

The block diagram that represents (17) is shown in Figure 2 


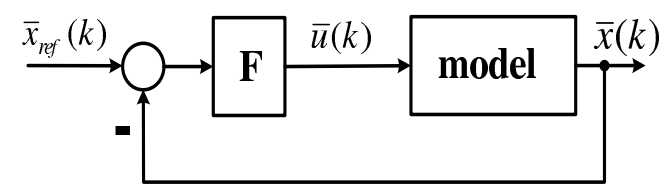

Fig. 2. Deadbeat block diagram.

\section{A. Deadbeat Power Control}

The power control scheme uses a deadbeat controller presented in section III to obtain rotor voltages which should be applied on generator in order to guarantee active and reactive power reach their desired reference values in $N$ samplings intervals. The sampling period $T$ has the same time of PWM modulator. The converter that is connected to the grid control the voltage of the link DC and one can be controlled by using a current control [21]. The deadbeat power control block diagram is shown in Figure 3.

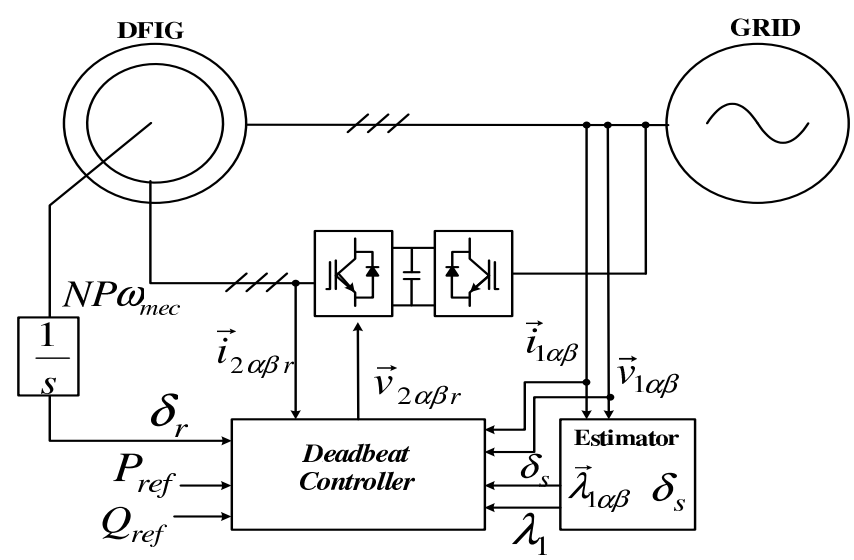

Fig. 3. Deadbeat power control block diagram.

The rotor equation (13) can be rewritten as a discrete equation using (15) and making $\bar{x}=\bar{i}_{2}, A=H, B=$ $K, \bar{u}=\bar{v}_{2}, G=L$ and $\bar{w}=\bar{i}_{1}$. It is given by equation (19)

$$
\begin{aligned}
& {\left[\begin{array}{c}
i_{2 d}(k+1) \\
i_{2 q}(k+1)
\end{array}\right]=} {\left[\begin{array}{cc}
1-\frac{R_{2} T}{\sigma L_{2}} & \frac{\omega_{s l} T}{\sigma} \\
\frac{-\omega_{s} T}{\sigma} & 1-\frac{R_{2} T}{\sigma L_{2}}
\end{array}\right]\left[\begin{array}{l}
i_{2 d}(k) \\
i_{2 q}(k)
\end{array}\right] } \\
&+\left[\begin{array}{cc}
\frac{T}{\sigma L_{2}} & 0 \\
0 & \frac{T}{\sigma L_{2}}
\end{array}\right]\left[\begin{array}{l}
v_{2 d}(k) \\
v_{2 q}(k)
\end{array}\right] \\
&+\left[\begin{array}{cc}
0 & \frac{\omega_{s l} L_{M} T}{\sigma L_{2}} \\
\frac{-\omega_{s l} L_{M} T}{\sigma L_{2}} & 0
\end{array}\right]\left[\begin{array}{l}
i_{1 d}(k) \\
i_{1 q}(k)
\end{array}\right]
\end{aligned}
$$

The rotor voltage which is calculated to guarantee null steady state error by using (18) and (19) is given by

$$
\begin{aligned}
v_{2 d}(k)= & \sigma L_{2} \frac{i_{2 d_{r e f}}-i_{2 d}(k)}{T}+R_{2} i_{2 d}(k) \\
& -L_{2} \omega_{s l} i_{2 q}(k)-L_{M} \omega_{s l} i_{1 q}(k) \\
v_{2 q}(k)= & \sigma L_{2} \frac{i_{2 q_{r e f}}-i_{2 q}(k)}{T}+R_{2} i_{2 q}(k) \\
& +L_{2} \omega_{s l} i_{2 d}(k)+L_{M} \omega_{s l} i_{1 d}(k)
\end{aligned}
$$

For the active power control, the reference of quadrature component of rotor current space vector is achieved by using
Equation (9) is given by

$$
i_{2 q}(k+1)=i_{2 q_{r e f}}=-\frac{2 P_{r e f} L_{1}}{3 v_{1} L_{M}}
$$

and for the reactive power control the reference of direct component of rotor current space vector is achieved by using Equation (10) is

$$
i_{2 d}(k+1)=i_{2 d_{r e f}}=-\frac{2 Q_{r e f} L_{1}}{3 v_{1} L_{M}}+\frac{\lambda_{1}}{L_{M}}
$$

The block diagram for deadbeat power control implementation is shown in Figure 4.

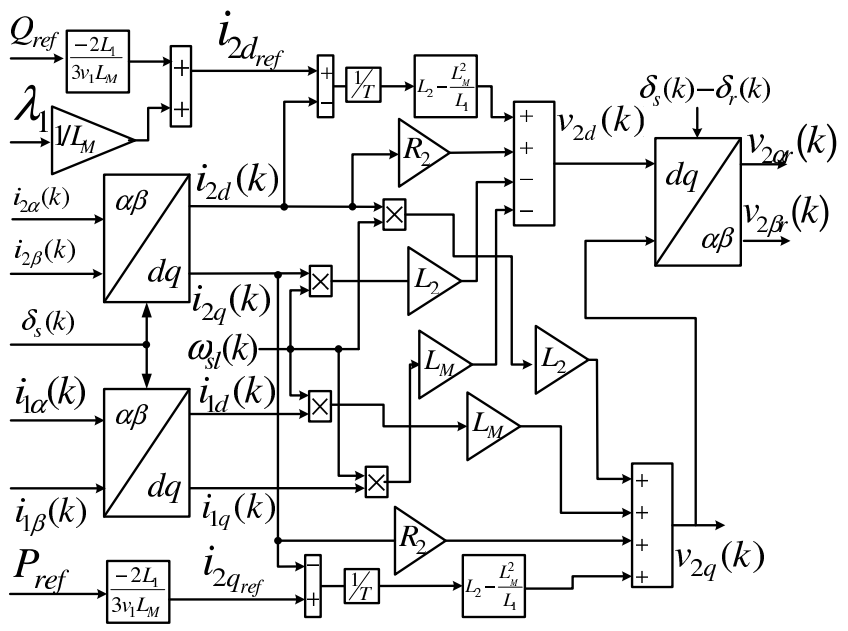

Fig. 4. Deadbeat power control block diagram for implementation.

Thus, if the $d$ and $q$ axis rotor voltage components are calculated according equations (20) and (21) above are applied to the generator, then the active and reactive power convergence to their respective commanded values will occur in a few sampling intervals. The desired rotor voltage in the rotor reference frame $\left(\delta_{s}-\delta_{r}\right)$ generates switching signals for the rotor side using either space vector modulation.

Stator currents and voltages, rotor speed and currents are measured to stator flux position $\delta_{s}$ and magnitude $\lambda_{1}$, synchronous frequency $\omega_{1}$ and slip frequency $\omega_{s l}$ estimation.

\section{B. Estimation}

To deadbeat power control, as show in the equation (21), it is necessary to calculate the active and reactive power values, their errors, the stator flux magnitude and position, the slip speed and synchronous frequency.

The flux estimation using (1) is given by

$$
\vec{\lambda}_{1 \alpha \beta}=\int\left(\vec{v}_{1 \alpha \beta}-R_{1} \vec{i}_{1 \alpha \beta}\right) d t
$$

This expression has been implemented for low speed operation in [22] based on method presented in [23] using the block diagram shown in Figure 5. 


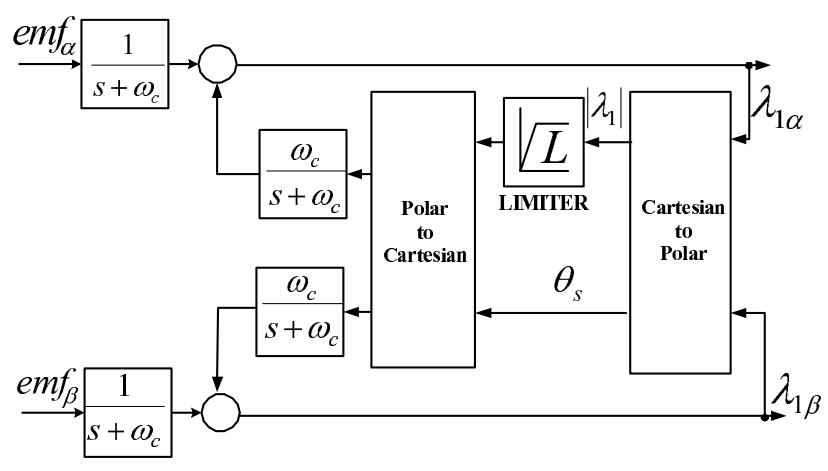

Fig. 5. Block diagram for stator flux estimation.

The flux position by using equation (24) as

$$
\delta_{s}=\arctan \left(\frac{\lambda_{1 \beta}}{\lambda_{1 \alpha}}\right)
$$

The synchronous speed $\omega_{1}$ estimation is given by

$$
\omega_{1}=\frac{d \delta_{s}}{d t}=\frac{\left(v_{1 \beta}-R_{1} i_{1 \beta}\right) \lambda_{1 \alpha}-\left(v_{1 \alpha}-R_{1} i_{1 \alpha}\right) \lambda_{1 \beta}}{\left(\lambda_{1 \alpha}\right)^{2}+\left(\lambda_{1 \beta}\right)^{2}}
$$

and the slip speed estimation by using the rotor speed and synchronous speed is

$$
\omega_{s l}=\omega_{1}-N P \omega_{m e c}
$$

The rotor angle in rotor reference frame is given by

$$
\delta_{s}-\delta_{r}=\int \omega_{s l} d t
$$

\section{EXPERIMENTAL RESULTS}

The deadbeat control strategy was implemented using a Texas Instruments DSP TMS320F2812 platform and also has a $T=410^{-4} s$. The system consists of a three-phase voltage source inverter with insulated-gate bipolar transistors (IGBTs) and the three-phase doubly-fed induction machine shown in the appendix. The stator voltage commands are modulated by using symmetrical space vector PWM, with switching frequency equal to $2.5 \mathrm{kHz}$. The DC bus voltage of the inverter is $36 \mathrm{~V}$ due to the fact the transformation relationship between stator winds and rotor winds is not one and it is used a transformer between the converter and the grid. The stator voltages and currents are sampled in the frequency of $2.5 \mathrm{kHz}$. The encoder resolution is 3800 pulses per revolution. The rotor voltage was limited using limiters in the dsp (digital signal processor) program. The speed is applied to the DIFG using a separately excited DC motor in open loop voltage control. The DFIG synchronization is made using the methods presented by [24-27]. The experimental setup is shown in Figure 6.

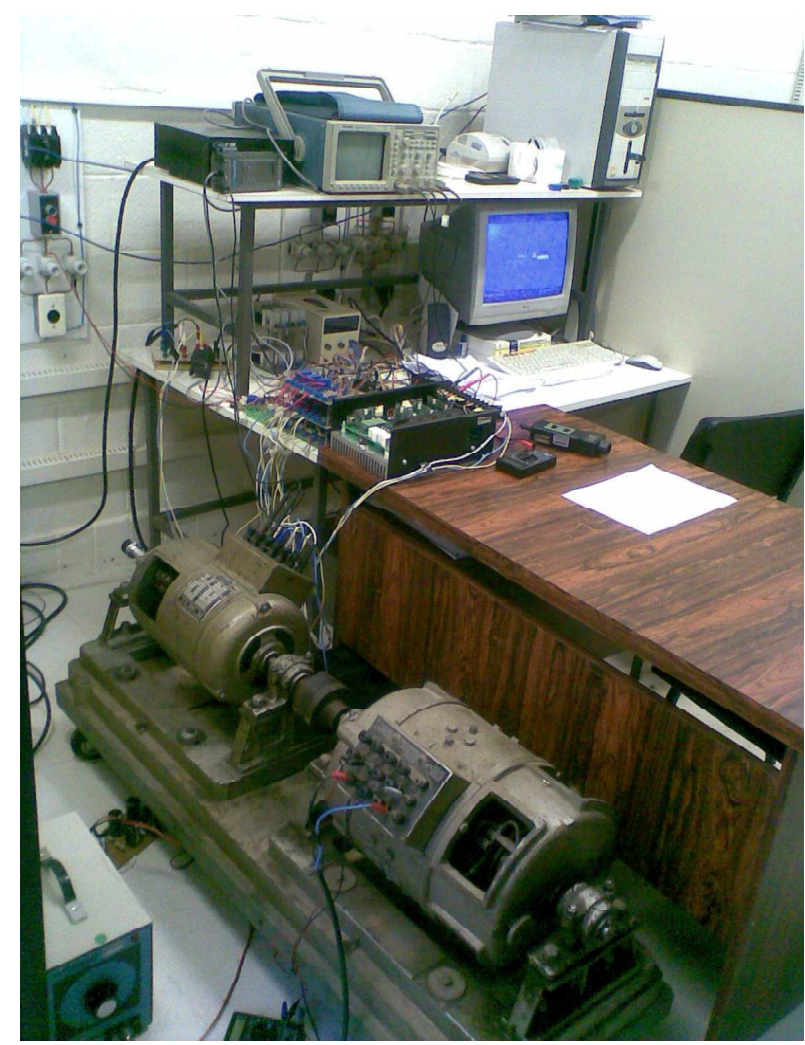

Fig. 6. Experimental setup.

Six tests were made, five in sub-synchronous speed operation and one in several speed operation. The first one was the response of $i_{2 d}$ step of $5 \mathrm{~A}$ which is shown in Figure 7. The satisfactory performance of controller can be seen due to the fact the reference is followed. In this test the $i_{2 q}$ is $0.5 \mathrm{~A}$. The rotor current reach the reference no more than $40 \mathrm{~ms}$.

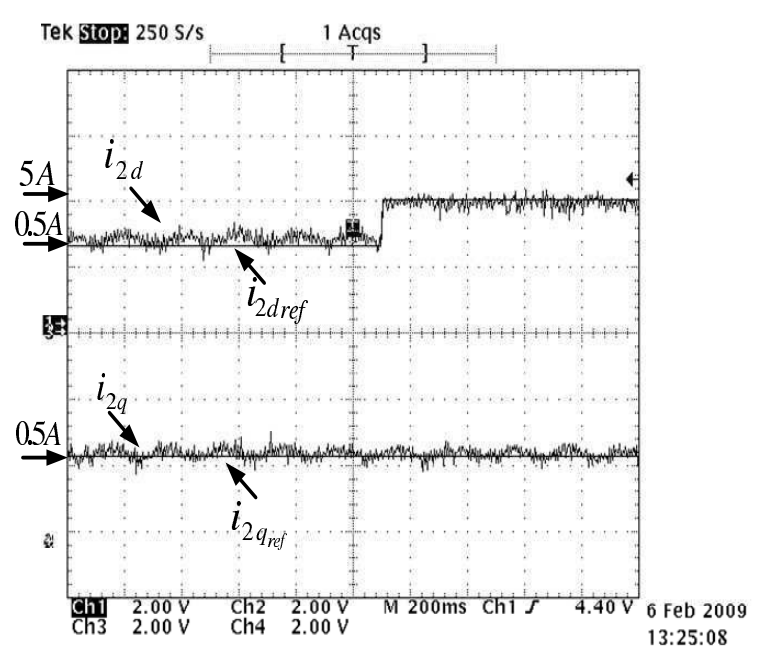

Fig. 7. Response of step test for $i_{2 d}$.

The second was the response of $i_{2 q}$ step of $5 \mathrm{~A}$. The satisfactory performance of controller in this test can be seen again in Figure 8 due to the fact the reference is followed. In this test $i_{2 d}$ is $4 \mathrm{~A}$. 


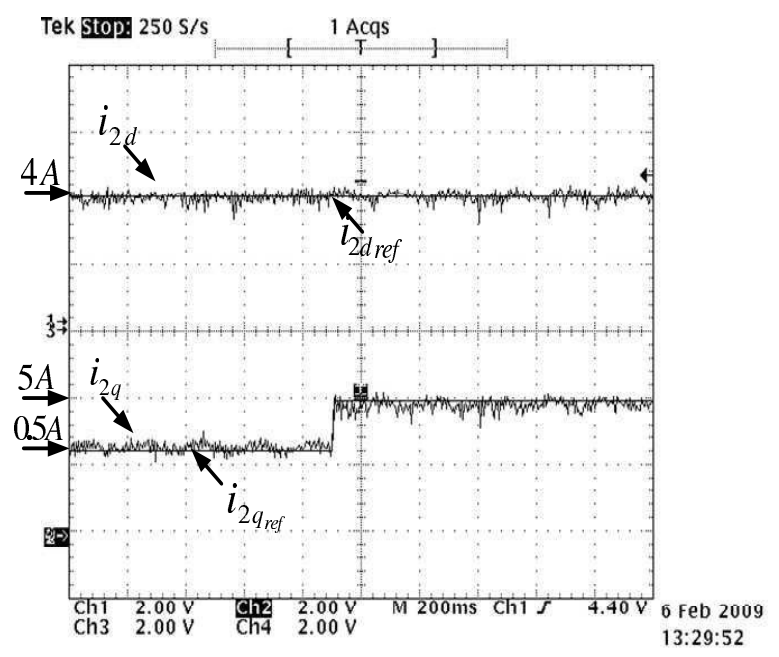

Fig. 8. Response of step test for $i_{2 q}$.

The same test of $i_{2 q}$ step of $5 \mathrm{~A}$ with rotor currents in rotor reference frame is presented in Figure 9. The satisfactory response of the controller can be seen due to the fact the reference is followed.

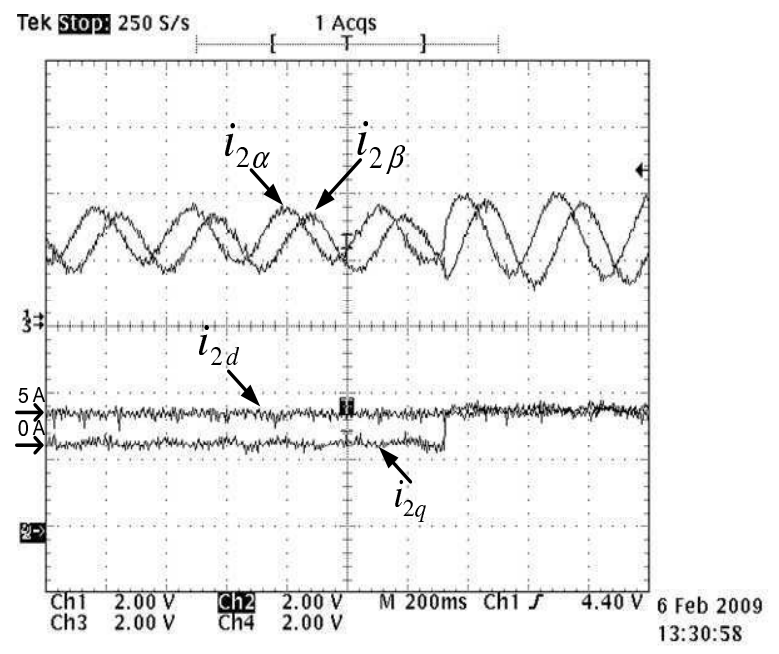

Fig. 9. Response of step test for $i_{2 q}$ and rotor currents (1.4A/div).

The fourth test is the response of reactive power $Q_{\text {ref }}$ of $-300 \mathrm{VA}, 300 \mathrm{VA}$ and $0 \mathrm{VA}$ which means leg, lead and unitary power factor. The satisfactory performance of the controller is can be seen again in Figure 10 due to the fact the reference is followed. The rotor currents are shown in Fig 11.

The fifth test is the steady state of unitary power factor and active power is $-300 \mathrm{~W}$. The rotor current reference are also calculated using Equations (22) and (23). The response of stator power and rotor current are presented in Figures 12 and 13 , respectively. The stator voltage (127Vrms) and the stator current (0.8Arms) of phase $\alpha$ is shown in Figure 14. It can be seen the satisfactory performance of the controller due to the fact the angle between the stator voltage and the stator current is $180^{\circ}$. The spikes occurs due to the fact the noise of the system and errors of measurements currents and voltages.

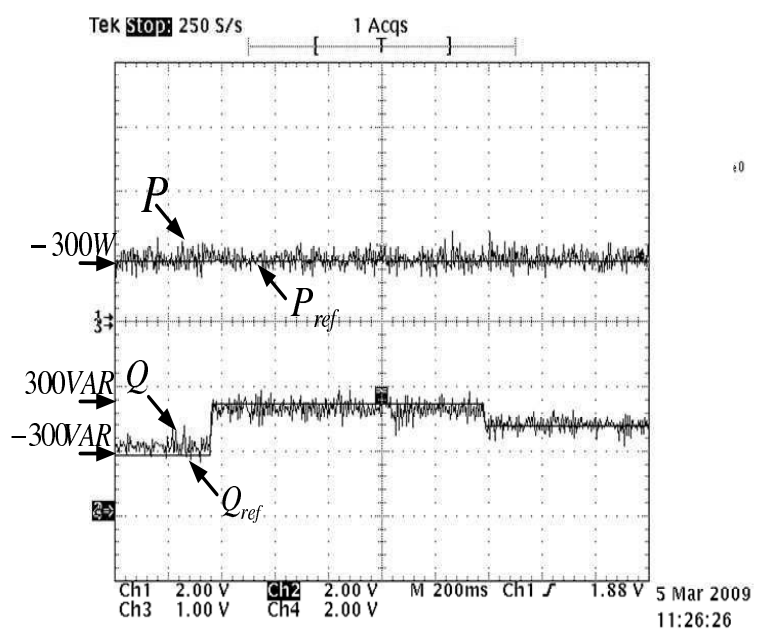

Fig. 10. Response of step test of reactive power.

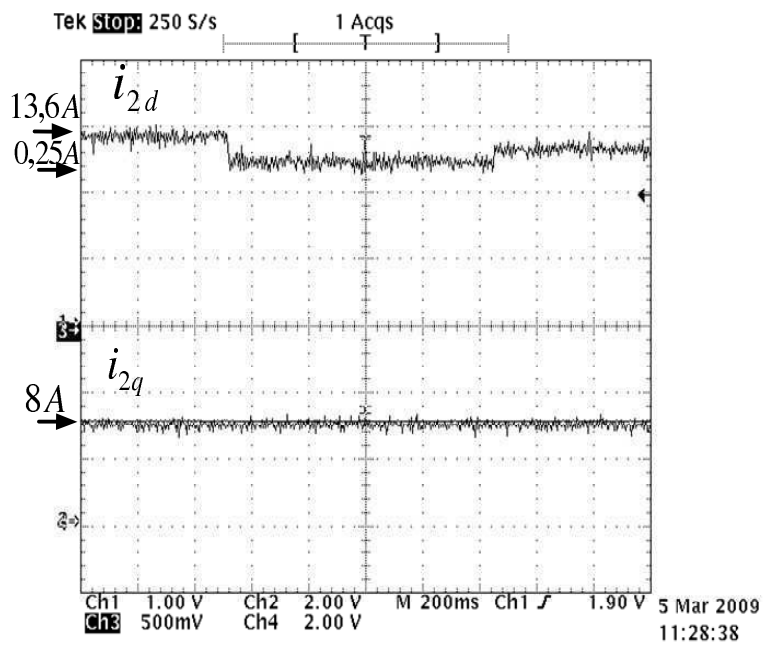

Fig. 11. Rotor currents of response of step test of reactive power.

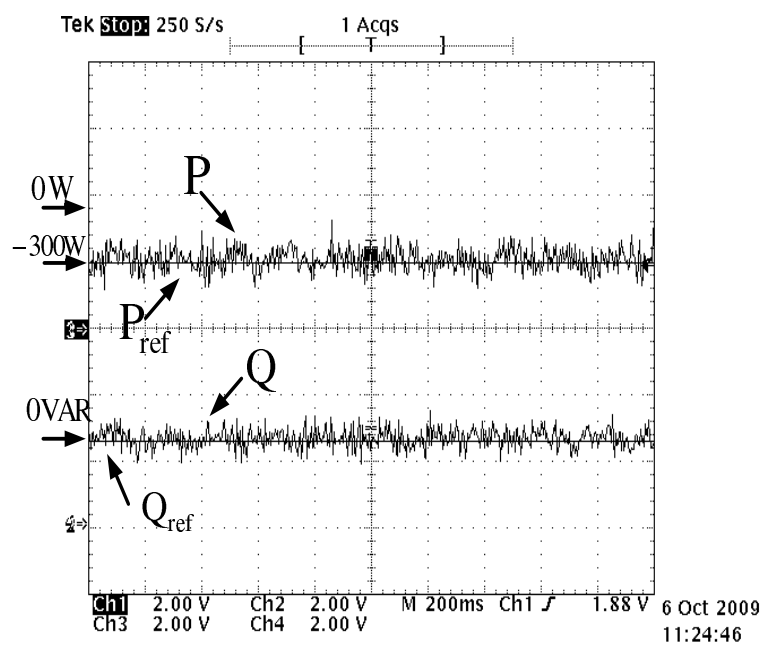

Fig. 12. Active and Reactive Power of DFIG. 


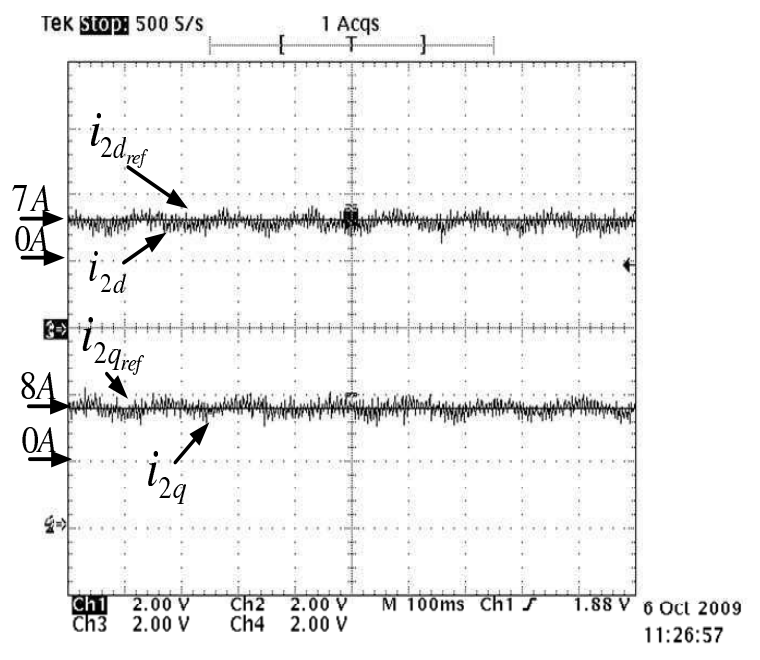

Fig. 13. Rotor current of DFIG.

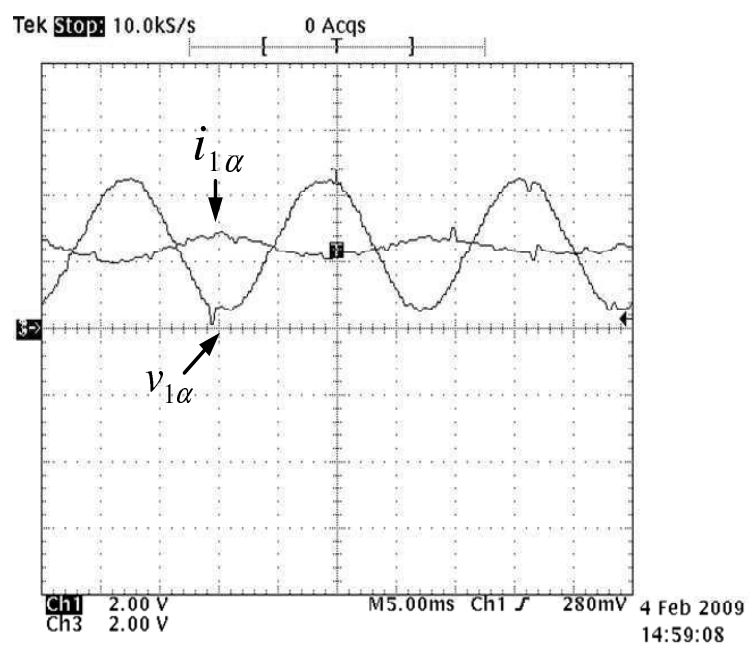

Fig. 14. Stator voltage (18 V/div.) and current (0.38 A/div.).

In the last test, the generator operates with several speed and a constant active and reactive power reference of $0 \mathrm{~W}$ and $0 \mathrm{VA}$, respectively. The rotor current reference are also calculated using Equations (22) and (23). In this case, this test just maintains the magnetization of the generator. The response of the active and reactive power is shown in Figure 15 and the rotor current is presented in Figure 16. The rotor speed in several operations and the rotor current of phase $\alpha$ is shown in Figure 17. The satisfactory performance of the controller is can be seen during several speed operation due fact the reference is followed and the DFIG operates from super-synchronous operation to sub-synchronous operation.

\section{CONCLUSION}

This paper has presented a deadbeat active and reactive power control for doubly fed induction generator. The controller uses the DFIG discretized dynamic equations to calculate the required rotor voltages in order to the active and the reactive power values reach the desired reference within a few sampling intervals due to the fact the controller response depends of the order of the system and the sampling period. The deadbeat control uses a rotor current control for this objective. This strategy operates with constant switching frequency that overcomes the drawbacks of conventional DPC $[28,29]$. Experimental tests with parameters variations have to be done to analyze the performance of the controller.

The experimental results confirm the effectiveness of the deadbeat power controller during several operating conditions.

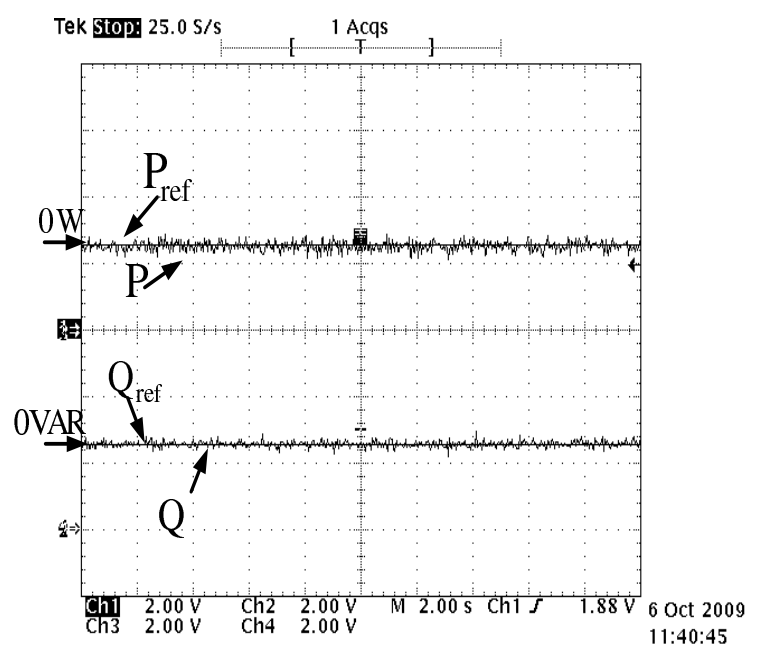

Fig. 15. Active and reactive power of DFIG.

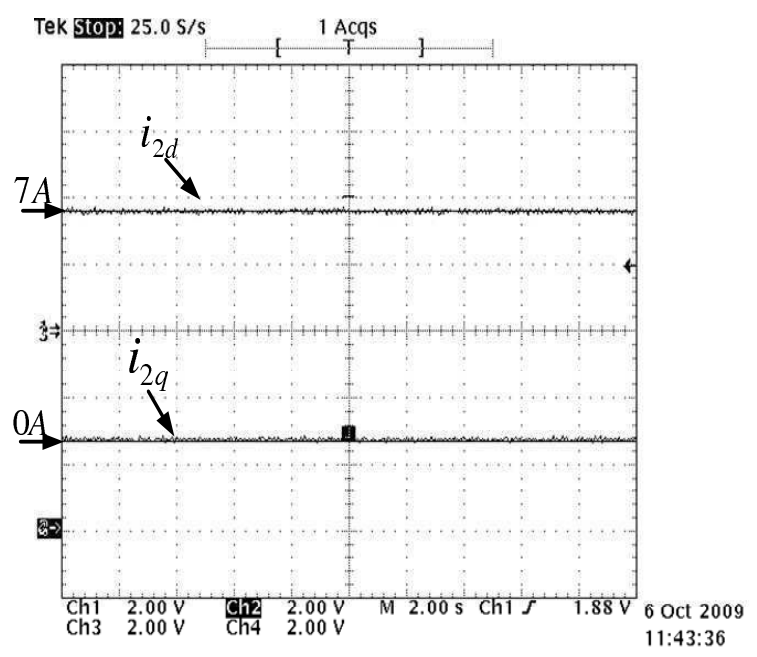

Fig. 16. Rotor current in steady state.

\section{ACKNOWLEDGEMENT}

The authors would like to thank to CAPES, FAPESP and CNPQ by the financial support and the Texas Instruments for the dsp donation. 


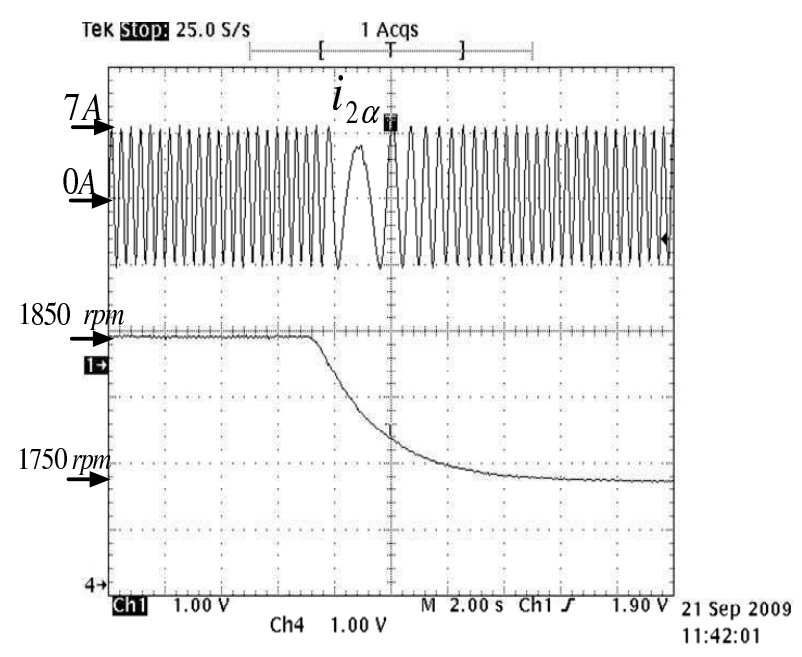

Fig. 17. Rotor current and speed of DFIG.

\section{REFERENCES}

[1] M. G. Simões and F. A. Farret, Renewable Energy Systems with Induction Generators. CRC PRESS, 2004.

[2] R. Datta and V. T. Rangathan, "Variable-speed wind power generation using doubly fed wound rotor induction machine - a comparison with alternative schemes," IEEE Trans. on Energy Conversion, vol. 17, no. 3, pp. 414-421, September 2002.

[3] B. H. Chowdhury and S. Chellapilla, "Double-fed induction generation control for variable speed wind power generation," Electric Power System Research, no. 76, pp. 786-800, 2006.

[4] B.Hopfensperger, D.J.Atkinson, and R. Lakin, "Stator-f lux-oriented control of a doubly-fed induction machine with and without position encoder," IEE Proc.-Electr. Power Applications, vol. 147, no. 4, pp. 241-250, April 2000.

[5] A. Tapia, G. Tapia, J. X. Ostolaza, and J. R. Sáenz, "Modeling and control of a wind turbine driven doubly fed induction generator," IEEE Trans. on Energy Conversion, no. 194-204, June 2003.

[6] F. K. de A. Lima, E. H. Watanabe, P. Rodríguez, and Álvaro Luna, "Modelo simplificado para aerogeradores equipados com gerador de indução duplamente alimentado," Eletrônica de Potência, vol. 16, no. 1, pp. $47-55,2011$.

[7] R. G. de Oliveira, J. L. da Silva, S. R. Silva, B. R. Junior, and W. Hofmann, "Desenvolvimento de uma nova estratégia de controle de potência reativa em gerador de indução de dupla alimentação para turbinas eólicas," Eletrônica de Potência, vol. 13, no. 4, pp. 277- 284, 2008.

[8] J. P. da Costa, J. Marques, H. A. Gründling, and H. Pinheiro, "Dynamic behavior of the doubly-fed induction generator in stator flux vector reference frame," Eletrônica de Potência, vol. 13, no. 1, pp. 33-42, March 2006.

[9] R. G. de Oliveira, J. L. da Silva, and S. R. Silva, "Development of a new reactive power control strategy in doubly-fed induction generators for wind turbines," Eletrônica de Potência, vol. 13, no. 4, pp. 277-284, November 2008.

[10] F. P. anb T. Bouaouiche and M. Machmoum, "Advanced control of a doubly-fed induction generator for wind energy conversion," Electric Power Systems Research, vol. 79, pp. 1085-1096, 2009.

[11] Z. Xin-fang, X. Da-ping, and L. Yi-bing, "Predictive functional control of a doubly fed induction generator for variable speed wind turbines," IEEE World Congress on Intelligent Control and Automation, June 2004.

[12] J. Morren and M. Sjoerd W. H. de Haan, "Ridethrough of wind turbines with doubly-fed induction generator during a voltage dip," IEEE Transactions on Energy Conversion, vol. 20, no. 2, pp. 435-441, June 2005.

[13] J. Guo, X. Cai, and Y. Gong, "Decoupled control of active and reactive power for a grid-connected doublyfed induction generator," Third International Conference on Electric Utility Deregulation and Restructuring and Power Technologies. DRPT 2008., pp. 2620 - 2625, April 2008.

[14] H. Nian, Y. Song, P. Zhou, and Y. He, "Improved direct power control of a wind turbine driven doubly fed induction generator during transient grid voltage unbalance," Energy Conversion, IEEE Transactions on, vol. 26, no. 3, pp. $976-986$, sept. 2011.

[15] A. J. S. Filho, M. E. de oliveira Filho, and E. Ruppert, "A predictive power control for wind energy," IEEE Transactions on Sustainable Energy, vol. 2, pp. 97 - 105, 2011.

[16] G. Xiao-Ming, S. Dan, H. Ben-Teng, and H. Ling-Ling, "Direct power control for wind-turbine driven doublyfed induction generator with constant switch frequency," International Conference on Electrical Machines and Systems, pp. 253-258, October 2007.

[17] A. J. S. Filho, M. de Oliveira Filho, and E. R. Filho, "A digital active and reactive power control for doublyfed induction generetator," IEEE Power Electronics Specialists Conference, PESC 2008., pp. 2718 - 2722, June 2008.

[18] A. J. S. Filho and E. Ruppert, "A deadbeat active and reactive power control for doubly-fed induction generators," Electric Power Components and Systems, vol. 38, no. 5, pp. 592-602, 2010.

[19] P. Sen, Principles of electric machines and power electronics. Ed. John Wiley, 1997.

[20] G. F. Franklin, J. D. Powel, and M. 1. Workman, Digital Control of Dynamic Systems. Addison-Wesley Publishing Company, 1994.

[21] J. R. Rodríguez, J. W. Dixon, J. R. Espinoza, J. Pontt, and P. Lezana, "Pwm regenerative rectifiers: State of the art," IEEE Transactions on Industrial Electronics, vol. 52, no. 1, February 2005.

[22] A. J. S. Filho and E. R. Filho, "The complex controller for three-phase induction motor direct torque control," Sba Controle e automação., vol. 20, no. 2, pp. 256-262, 2009.

[23] J. H. B. Wu, "New integration algorithms for estimating motor flux over wide speed range," IEEE Trans. on Power 
Electronics, vol. 13, no. 5, pp. 969-977, September 1998.

[24] A. G. Abo-Khalil, D.-C. Lee, and S.-H. Lee, "Grid conection of doubly-fed induction generators in wind energy conversion system," IPEMC '09. IEEE 6th International Power Electronics and Motion Control Conference., 2006.

[25] A. Tennakoon, A. Arulampalam, J. B. Ekanayake, and S. G. Abeyratne, "Tracking of rotor angle for controlling doubly fed induction generators in wind power applications," International Conference on Industrial and Information Systems. ICIIS., pp. 311 316, 2007.

[26] W. Sadara and B. Neammanee, "Implementation of three phase grid synchronization for doubly-fed induction generators in wind energy systems," International Conference on Electrical Engineering/Electronics Computer Telecommunications and Information Technology ECTI-CON, pp. 1016 - 1020, 2010.

[27] A. J. S. Filho, “ Controle de Potências Ativa e Reativa de Geradores de Indução Trifásicos de Rotor Bobinado para Aplicação em Geração Eólica com a Utilização de Controladores Baseados no Modelo Matemático Dinâmico do Gerador," Universidade Estadual de Campinas - UNICAMP, Tese Doutorado, 2010.

[28] R. Datta and V. T. Ranganathan, "Direct power control of grid-connected wound rotor induction machine without rotor position sensors," IEEE Transactions on Power Electronics, vol. 16, no. 3, pp. 390 - 399, May 2001.

[29] L. Xu and P. Cartwright, "Direct active and reactive power control of dfig for wind energy generation," IEEE IEEE Transactions on Energy Conversion, vol. 21, no. 3, pp. 750-758, September 2006.

\section{APPENDIX}

Doubly-fed induction generator parameters: $R_{1}=2.2 \Omega$; $R_{2}=1.764 \Omega ; L_{m}=0.0829 \mathrm{H} ; L_{l 1}=0.0074 \mathrm{H} ; L_{l 2}=$ $0.0074 \mathrm{H} \mathrm{H} ; J=0.05 \mathrm{Kg} \cdot \mathrm{m}^{2} ; N P=2 ; P N=2.25 \mathrm{KW}$; $V_{N}=220 \mathrm{~V}$.

\section{BIOGRAPHIES}

Alfeu J. Sguarezi Filho received his bachelor degree in Electrical Engineering from Faculdade Área 1, his Master degree and his $\mathrm{Ph}$. D. degree from Campinas University in Brazil, respectively in 2005, 2007 and 2010. He is working as researcher at Campinas University by FAPESP pos-doctoral program. His research interests are machine drives, doubly-fed induction generators, power control, and electrical power systems. Mr Sguarezi Filho is a member of SOBRAEP since June 2007 and IEEE since 2004

José Luis Azcue Puma received his Bachelor degree in Electronic Engineering in 2004 from Universidad Nacional del Altiplano, Puno, Peru, and the MSc degree in 2010 from University of Campinas (UNICAMP), Campinas, Brazil. He is currently pursuing his PhD studies at School of Electrical and Computer Engineering at UNICAMP. His primary areas of interest are electrical machines, ac drives, power electronics, intelligent electrical drives, fuzzy controllers and fuzzy systems.

Tárcio André dos Santos Barros was born in Petrolina, Brazil, on September 19, 1987. He received the B.Sc. Degree in electrical engineering from Universidade Federal do Vale do São Francisco
(UNIVASF), Brazil, in 2010. He is currently a graduate student in electrical engineering from Universidade Estadual de Campinas (UNICAMP) , Brazil. His main areas of interest are electrical machines and drives.

Milton E. de Oliveira Filho was born in Bom Jesus da Lapa, Bahia, 1966. He graduated as electrical engineer from Universidade Federal de Itajubá, Itajubá (1995) and as MSc in same university (1998) and Ph. D. degree from Campinas University (2010) in Brazil. $\mathrm{He}$ is currently working as researcher at Campinas University by CAPES-PNPD pos-doctoral program, Brazil. His research interests are matrix converters, active power filters, and large power drives. $\mathrm{Mr}$ Milton is a member of SOBRAEP since June 2007.

Ernesto Ruppert Filho received his bachelor degree in Electrical Engineering and his Master and $\mathrm{PhD}$ degrees from Campinas University in Brazil, respectively in 1971, 1974 and 1983. From 1972 to 1978 he had been working at Electrical and Computer Enginneering School of Campinas University as an Assistance Professor in the Electromechanical Energy Conversion area, from 1979 to 1983 he had been working for General Electric in Brazil designing large induction and synchronous motors and working as Application Engineer in large motors and generators, from 1983 to 1989 he had been working for Vigesa Heavy Equipments in Brazil designig very large hydrogenerators and also performing commissionig testes in some hydro power plants in Brazil. From 1989 to 1992 he runned his own company dealing with electrical installations and from 1992 up to now he is working as Full Professor at the Electrical and Computer Engineering School of Campinas University, in Campinas, Brazil, researching and teaching in the areas of Electrical Machines, Power Electronics, Drives and Electrical Power Systems. 